\title{
Sistem Informasi Absensi Haul Berbasis Web di Pondok Pesantren Muhyiddin Surabaya
}

\author{
Erliyah Nurul Jannah ${ }^{1}$, Agus Zainal Arifin ${ }^{2}$ \\ ${ }^{1}$ Sistem Informasi, Fakultas Teknik, Universitas Pesantren Tinggi Darul 'Ulum (Unipdu), Jombang \\ ${ }^{2}$ Teknik Informatika, Fakultas Teknologi Informasi, Institut Teknologi Sepuluh Nopember (ITS), Surabaya \\ E-mail: 1erliyah.nj@ft.unipdu.ac.id, ${ }^{2}$ agusza@cs.its.ac.id
}

\begin{abstract}
Abstrak
Teknologi informasi saat ini telah menjadi kebutuhan bagi hampir semua instansi, baik pemerintah maupun swasta. Tak terkecuali pondok pesantren, khususnya Pondok Pesantren Muhyiddin Surabaya. Berbagai permasalahan di pondok pesantren membutuhkan bantuan teknologi informasi dalam penyelesaiannya. Salah satunya adalah permasalahan pencatatan kehadiran peserta dalam suatu acara tertentu seperti acara Haul. Haul merupakan acara tahunan yang bertujuan untuk memperingati hari lahirnya Nabi Muhammad SAW. Acara Haul di PP. Muhyiddin mendatangkan lebih dari seribu peserta yang merupakan penghafal Quran. Panitia Haul harus mengabsen peserta satu persatu serta menempatkannya ke majelis-majelis berdasarkan urutan kedatangan dan kota asal. Sistem informasi absensi yang ada masih berbasis desktop dan hanya mampu digunakan untuk mengabsen peserta saja. Sistem tersebut belum mampu melakukan pembagian majelis peserta secara otomatis. Padahal proses pembagian majelis inilah yang menyebabkan proses absensi memakan waktu lama. Oleh sebab itu, dibuatlah sebuah Sistem Informasi Absensi Haul yang berbasis web. Sistem ini diharapkan mampu untuk membuat proses absensi pada acara Haul menjadi lebih efisien. Dari hasil pengujian sistem yang telah dilakukan, dalam satu menit sistem dapat digunakan untuk mengabsen sepuluh peserta, membagi peserta tersebut ke majelis-majelis, dan mencetak kartu peserta Haul.
\end{abstract}

Kata kunci: sistem informasi absensi, Haul, pembagian majelis peserta.

\begin{abstract}
Information technology has become a necessity for almost institutions, both public and private. There is no exception for boarding schools, especially Muhyiddin boarding school Surabaya. Various problems in boarding school need information technology to assist the jobs. One of them is problem in recording attendance of participants in a particular event such as Haul. Haul is an annual event that aims to celebrate the birth of Prophet Muhammad. Haul which was held in PP. Muhyiddin called more than a thousand participants who are the Quran memorizers (Hafiz). Haul committee must record the participants' attendances one by one and place them into rooms (majelis) based on the order of arrival and city of origin. The existing information system is a desktop-based application that only can be used to record the participants' attendances. The system has not been able to distribute the participants in to majelis automatically. While the distribution process is the thing that causes the attendance recording process takes a long time. Therefore, we proposed an Information System for Recording Haul Participants' Attendances. The system is expected to be able to make the attendances recording process at Haul become more efficient. From the results of system testing has been done, within one minute the system can be used to record ten participants' attendance, distribute the participants into majelis, and print ID Card for the participants.
\end{abstract}

Key word: attendance information systems, Haul, participants' distribution into majelis .

\section{Pendahuluan}

Teknologi informasi saat ini telah banyak diterapkan di berbagai instansi, baik pemerintah maupun swasta. Hal ini terjadi karena keberadaannya sangat berguna untuk memudahkan pekerjaan manusia. Dengan adanya teknologi informasi, suatu pekerjaan dapat diselesaikan dengan lebih efektif dan efisien.

Sistem informasi merupakan salah satu wujud dari teknologi informasi yang banyak sekali digunakan. Menurut (Bodnar \& Hopwood, 2004), sistem informasi adalah kumpulan perangkat keras dan perangkat lunak yang dirancang untuk mentransformasikan data dalam bentuk informasi yang 
berguna). Terdapat berbagai macam sistem informasi, diantaranya adalah sistem informasi manajemen, sistem informasi akuntansi, dan sistem informasi absensi.

Sistem informasi absensi merupakan sistem informasi yang sangat berguna untuk mencatat kehadiran peserta. Selama ini, sistem informasi absensi hanya sering diterapkan pada proses perkuliahan atau proses belajar mengajar dan absensi kehadiran pegawal. Padahal, sistem informasi absensi juga dapat diterapkan di acara atau kegiatan lain, seperti acara Haul di Pondok Pesantren Muhyiddin Surabaya.

Pondok pesantren Muhyiddin merupakan pondok pesantren khusus anak-anak yang beralamatkan di Jalan Gebang Kidul Sukolilo, Surabaya. Setiap tahunnya pondok pesantren ini mengadakan pertemuan yang dinamakan Haul dalam rangka memperingati maulid Nabi Muhammad SAW dan Syeikh Abdul Qodir Jailani. Acara ini dihadiri oleh lebih dari seribu penghafal Quran (hafidz dan hafidzoh) yang berasal dari sebagian besar wilayah di Indonesia.

Acara Haul diadakan selama dua hari. Hari pertama diperuntukkan bagi para penghafal putra (hafidz), dan hari kedua untuk penghafal putri (hafidzoh). Setiap peserta diberi nomor identitas berupa kode huruf dan angka yang mengidentifikasikan kota asal dan jenis kelamin peserta. Dalam sehari, panitia dituntut untuk dapat mencatat semua peserta yang hadir yang berjumlah lebih dari lima ratus orang. Selain itu, peserta juga perlu dibagi-bagi ke dalam majelis berdasarkan urutan kedatangan da nasal kota. Dalam satu majelis berisi maksimal tiga orang yang harus berasal dari kota yang berbeda. Kemudian panitia harus mencetak kartu peserta Haul yang berisi nomor identitas dan nomor majelis peserta yang telah diabsen.

Proses pencatatan kehadiran peserta Haul tersebut diakukan secara manual oleh beberapa panitia. Sistem manual ini menyebabkan proses absensi membutuhkan waktu lama. Oleh sebab itu, dibuatlah sebuah sistem informansi absensi untuk membantu proses absensi acara Haul. Sistem informasi absensi berbasis desktop yang telah dibuat ini ternyata hanya mampu digunakan untuk mengabsen peserta saja. Sistem tersebut belum mempunyai fasilitas registrasi peserta. Selain itu, sistem ini juga belum bisa membagi majelis secara otomatis berdasarkan urutan kedatangan dan kota asal. Sehingga proses pembagian majelis masih dilakukan secara manual. Panitia perlu memeriksa nomor identitas peserta untuk dapat melakukan proses pencatatan dan pembagian majelis. Proses penentuan majelis secara manual ini tidak hanya memakan waktu lama, namun juga membutuhkan ketelitian tinggi. Jika proses tersebut dilakukan oleh manusia, maka akan rawan sekali terjadi kekeliruan, khususnya dalam pembagian majelis. Peserta yang telah datang dan mengantri untuk diabsen pun akan keberatan jika harus menunggu lama.

Untuk mengatasi permasalahan tersebut, maka dibutuhkan suatu sistem informasi yang dapat membantu proses absensi Haul di Pondok Pesantren Muhyiddin. Sistem informasi yang akan dibangun diharapkan dapat mempermudah dan mempercepat proses absensi peserta Haul. Dengan hanya memasukkan nama dan nomor identitas peserta yang hadir, sistem diharapkan dapat secara otomatis mencatat peserta ke dalam database kehadiran dan juga sekaligus menentukan nomor majelis peserta berdasarkan urutan kedatangan dan kota asal. Sistem juga akan dilengkapi dengan fasilitas registrasi dan undang peserta. Sehingga peserta dapat mendaftar sebagai peserta Haul tanpa harus datang ke PP. Muhyiddin Surabaya. Pihak panitia pun lebih mudah dalam mendata peserta yang diundang.

\section{Metode Penelitian}

Beberapa penelitian tentang sistem informasi absensi telah dilakukan sebelumnya. Penelitian tersebut pada umumnya berfokus pada otomasi proses absensi dan penggunaan identitas untuk proses absensi. Ada yang menggunakan sidik jari sebagai identitas, ada pula yang menggunakan nomor identitas seperti nomor induk mahasiswa sebagai identitas pembeda antara satu dengan lainnya. (Santoso, Setiawan, \& Purwanto, 2010) telah membangun sistem informasi absensi untuk mencatat kehadiran dosen dan karyawan pada Universitas Kristen Petra. Sistem yang dibuat tersebut berguna untuk membantu pengambilan keputusan tentang penerimaan gaji berdasarkan presensi. Sedangkan (Subair, 2010), (Suprihatin \& Nurhantara, 2011), dan (Nuh, 2012) membuat sistem informasi presensi kehadiran mahasiswa dengan menggunakan sidik jari sebagai input sistem.

Keempat sistem informasi absensi yang telah diusulkan tersebut dibuat untuk mencatat kehadiran pegawai atau mahasiswa serta menampilkan laporan kehadiran. Sedangkan sistem yang akan dibuat dalam penelitian ini dirancang tidak hanya untuk mencatat kehadiran peserta dan memberikan laporan 
daftar kehadiran, namun juga dapat melakukan pembagian majelis peserta Haul secara otomatis berdasarkan urutan kedatangan dan kota asal peserta.

Pondok Pesantren Muhyiddin didirikan dengan tujuan untuk membangun masyarakat Islam menjadi umat yang bermanfaat bagi agama dan bangsa. Pondok Pesantren sebagai tolok ukur perkembangan islam saat ini sudah menjadi kepercayaan masyarakat sebagai pembangun akhlak bangsa yang sudah mulai merosot.

Pondok Pesantren Muhyiddin dibangun di atas lahan seluas $\pm 5000 \mathrm{~m}^{2}$ dan beralamat di Jl. Gebang Kidul No. 64-68. PP. Muhyiddin bergerak untuk membina generasi-generasi Qur'an yang nantinya akan terjun di masyarakat sebagai pendongkrak pembangunan akhlakul karimah.

Dengan latar belakang pondok pesantren yang berkonsentrasi pada pendidikan Al Qur'an (Hafidzil Qur'an) dan pemahaman Al Qur'an mudah-mudahan menjadikan pondok pesantren ini langgeng, demi kemajuan Islam di masa yang akan dating, dan menjadikan pembangunan bangsa ini maju dengan diikuti dengan membaiknya akhlak di masyarakat.

Motto dari PP. Muhyiddin adalah "Membangun generasi Qur'ani yang berakhlak Al Qur'an". Acara Haul yang diadakan di Pondok Pesantren Muhyiddin adalah sebuah acara yang dilaksanakan untuk memperingati hari lahir Nabi Muhammad SAW dan Syeikh Abdul Qodir Al Jailani. Acara ini diadakan pada tanggal 12-15 Robiul Akhir (biasanya sekitar bulan Februari atau Maret). Adapun kegiatan yang dilakukan pada acara tersebut adalah sebagai berikut:

a. Pembacaan Doa.

b. Menghafalkan (Hifdzil) Quran untuk peserta putra di hari pertama dan menghafalkan (Hifdzil) Quran untuk putri di hari kedua.

c. Pembacaan sholawat Nabi Muhammad SAW.

Acara ini dihadiri oleh lebih dari seribu penghafal Quran dari hampir seluruh wilayah Indonesia. Mereka sengaja diundang oleh panitia untuk ikut serta melaksanakan acara Haul. Undangan dan kartu identitas biasanya dikirim melalui pos. Para penghafal Quran di Indonesia yang tidak mendapatkan undangan untuk datang dapat mendaftar ke panitia melalui telepon. Selanjutnya mereka akan diundang untuk datang di acara Haul tahun berikutnya.

\subsection{PHP dan MySQL}

PHP merupakan singkatan dari Hypertex Preprocessor yang digunakan sebagai bahasa script server-side dalam pengembangan Web yang disisipkan pada dokumen HTML. Penggunaan PHP memungkinkan Web dapat dibuat dinamis, sehingga situs Web tersebut menjadi lebih mudah dan efisien.

PHP memiliki banyak kelebihan yang tidak dimiliki oleh bahasa script sejenis. PHP difokuskan pada pembuatan script server-side, yang bisa melakukan apa saja yang dapat dilakukan oleh CGI, seperti mengumpulkan data dari form, menghasilkan isi halaman web dinamis, dan kemampuan mengirim serta menerima cookies, bahkan lebih daripada kemampuan CGI.

PHP dapat digunakan pada semua sistem operasi, antara lain Linux, Unix (termasuk variannya HP-UX, Solaris, dan OpenBSD), Microsoft Windows, Mac OS X, RISC OS. PHP juga mendukung banyak Web Server, seperti Apache, Microsoft Internet Information Server (MIIS), Personal Web Server (PWS), Netscape and iPlanet servers, Oreilly Website Pro server, audium, Xitami, OmniHTTPd, dan lain-lain.

Salah satu fitur yang dapat diandalkan oleh PHP adalah sangat mendukung untuk digunakan pada banyak database. Database tersebut seperti AdabasD, dBase, Empress, FilePro, FrontBase, Hyperwave, mSQL, MySQL, ODBC, Oracle, Postgres, sybase,Velocis.

MySQL adalah salah satu database di mana PHP dapat diterapkan. MySQL sendiri adalah sebuah sistem manajemen basis data (Database Management System) yang multithread dan multiuser. Ia bersifat open source sehingga setiap orang dapat menggunakannya dengan gratis. Saat ini, sekitar enam juta orang telah menggunakan MySQL. berikut:

Beberapa keunggulan MySQL yang membuatnya diminati oleh banyak orang adalah sebagai

a. MySQL dapat diaplikasikan pada berbagai sistem operasi, baik Windows, Linux, Mac OS, dan lain sebagainya.

b. Bersifat open source. 
c. Multiuser, yaitu MySQL dapat digunakan oleh beberapa pengguna dalam waktu yang bersamaan.

d. MySQL mempunyai banyak jenis tipe data.

e. MySQL memiliki beberapa lapis level keamanan.

f. MySQL mampu menangani basis data dalam skala besar, dengan jumlah rekaman (records) lebih dari 50 juta dan 60 ribu tabel serta 5 miliar baris. Selain itu batas indeks yang dapat ditampung mencapai 32 indeks pada tiap tabelnya.

g. MySQL dapat melakukan koneksi dengan klien menggunakan protokol TCP/IP, Unix soket (UNIX), atau Named Pipes (NT).

h. MySQL dapat mendeteksi pesan kesalahan pada klien dengan menggunakan lebih dari dua puluh bahasa.

i. MySQL memiliki antar muka (interface) terhadap berbagai aplikasi dan bahasa pemrograman dengan menggunakan fungsi API (Application Programming Interface).

j. MySQL dilengkapi dengan berbagai peralatan (tools) yang dapat digunakan untuk administrasi basis data, dan pada setiap peralatan yang ada disertakan petunjuk online.

k. MySQL memiliki struktur tabel yang lebih fleksibel dalam menangani ALTER TABLE, dibandingkan basis data lainnya semacam PostgreSQL ataupun Oracle.

\subsection{Analisis Sistem Berjalan}

Sebelum acara Haul dilaksanakan, panitia telah mengirim undangan ke seribu lebih penghafal Quran di Indonesia. Selain surat undangan, mereka juga mengirim kartu identitas peserta. Kartu ini berisi nomor identitas, nama peserta, tempat tanggal lahir, dan kota asal peserta. Peserta yang telah diundang dan datang ke acara Haul diminta untuk menunjukkan surat undangan dan kartu identitas peserta. Panitia akan mencatat peserta tersebut ke daftar hadir. Panitia juga akan memastikan apakah peserta yang hadir tersebut orang yang sebenarnya atau kah wakil dari peserta yang diundang. Jika peserta yang diundang berhalangan hadir, mereka dapat mengirim utusan atau wakil sebagai pengganti. Namun merka harus memberikan surat undangan dan kartu identitasnya ke wakilnya. Jika peserta yang datang tersebut merupakan wakil, maka akan dimasukkan ke daftar peserta yang diwakilkan. Setelah itu, panitia akan menempatkan peserta yang datang tersebut ke majelis peserta. Di dalam majelis, peserta diminta untuk menghafalkan ayat-ayat Quran bersama dengan peserta lain.

Masalah sering kali timbul pada saat penempatan majelis peserta. Panitia harus menentukan nomor majelis peserta. Proses penentuan majelis ini memiliki beberapa aturan yaitu:

a. Digit kedua dan ketiga dari nomor identitas peserta menunjukkan kode kota asal peserta.

b. Dalam satu majelis hanya boleh berisi maksimal tiga orang peserta.

c. Dalam satu majelis, tidak boleh ada peserta berasal dari kota yang sama.

Proses penentuan atau pembagian majelis ini dapat dijelaskan lebih detail melalui diagram alir pada Gambar 1.

Setelah peserta ditempatkan ke majelis tertentu, maka panitia akan memberikan kartu peserta haul. Kartu ini berupa selembar kertas yang berisi tidak hanya nomor majelis peserta, namun juga keterangan lain seperti informasi identitas peserta, dan status kehadiran. Alur proses absensi pada acara Haul dirangkum pada Gambar 2.

PP. Muhyiddin selama ini telah menggunakan sistem informasi absensi yang berbasis desktop. Kekurangan dari sistem tersebut adalah tidak adanya fasilitas pembagian majelis secara otomatis. Padahal pembagian majelis ini sangat krusial dalam proses absensi acara Haul. Selain itu, sistem tersebut juga belum memiliki fasilitas registrasi dan undang peserta. Sistem yang berbasis desktop juga tidak dapat digunakan oleh beberapa orang dalam waktu yang bersamaan. Sehingga proses absensi masih belum efisien.

\subsection{Analisis Sistem yang Diusulkan}

Analisis sistem dalam penelitian ini meliputi analisis kebutuhan fungsional dan non fungsional sistem.

\section{Analisis Kebutuhan Fungsional}

Pengguna dari sistem informasi absensi Haul ini dibagi menjadi dua berdasarkan hak aksesnya, yaitu admin dan non-admin. Karakteristik dari admin dan non-admin dirangkum pada Tabel 1. 
Secara umum, perbedaan admin dan non-admin terletak pada hak akses untuk mengabsen peserta, mengundang peserta, dan melakukan pengaturan terhadap majelis peserta. Pengaturan majelis peserta ini meliputi menghapus data seluruh majelis majelis dan me-reset data majelis peserta. Maksud dari mereset majelis peserta adalah mengubah nomor majelis semua peserta pada database menjadi NULL. Hal ini berarti peserta dikembalikan ke status awal yaitu belum terbagi ke majelis-majelis. Sehingga untuk Haul tahun berikutnya, akan dilakukan proses absensi dan pembagian majelis lagi.

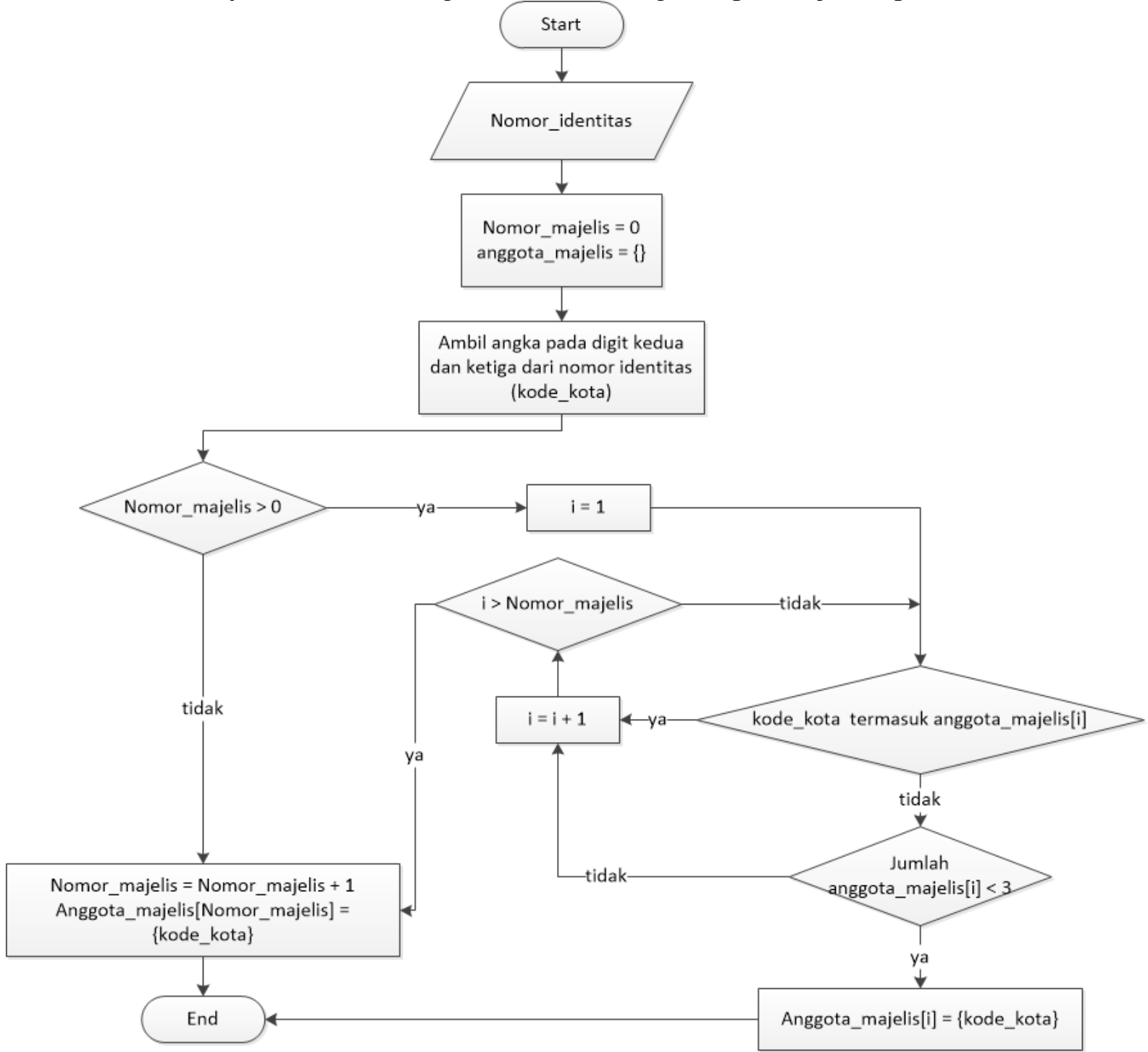

Gambar 1 Algoritma penentuan atau pembagian majelis peserta Haul

\section{Analisis Kebutuhan Non-Fungsional}

Adapun kebutuhan non-fungsional dari sistem informasi asrama ini adalah sebagai berikut:

a. User Friendly, sistem informasi yang akan dibuat harus mudah digunakan, khususnya untuk panitia Haul yang sebagian besar baru mengenal teknologi informasi.

b. Availability, sistem infromasi Haul akan digunakan selama acara Haul dilaksanakan, sistem tidak perlu on selama 24 jam non-stop.

c. Security, sistem ini dilengkapi dengan halaman login yang hanya dapat diakses oleh user (pengguna) yang memiliki username dan password saja.

\subsection{Perancangan Sistem}

Penulis mendekomposisi sistem yang akan dibangun ke dalam beberapa modul berdasarkan fungsinya. Modul-modul tersebut adalah modul registrasi, modul $\log$ in peserta, modul verifikasi dan undang, modul absensi, modul laporan peserta, modul majelis, dan modul pengaturan majelis. Keempat modul tersebut dijelaskan pada Tabel 1. 


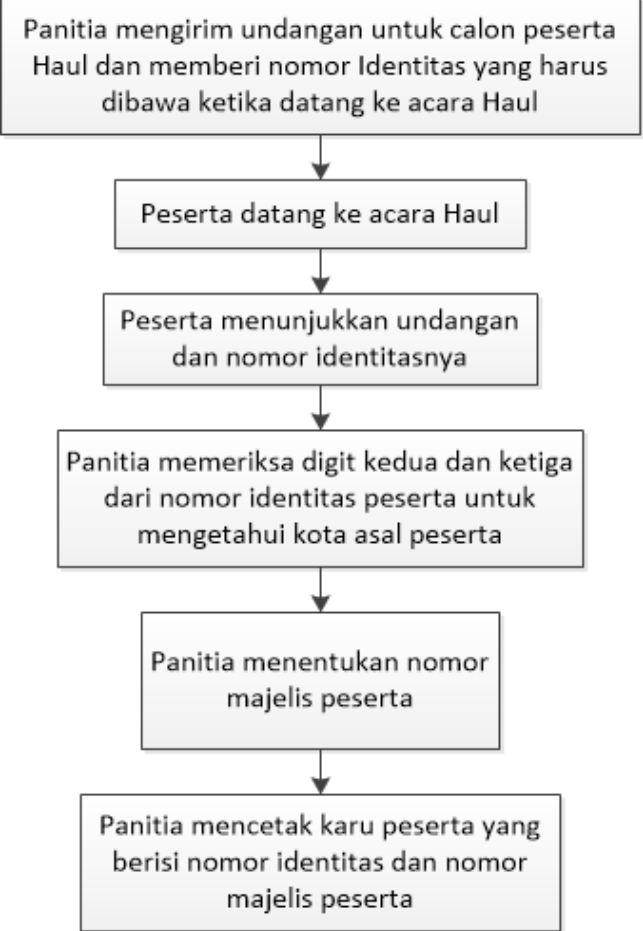

Gambar 2 Alur proses absensi peserta Haul yang dilakukan tanpa bantuan komputer

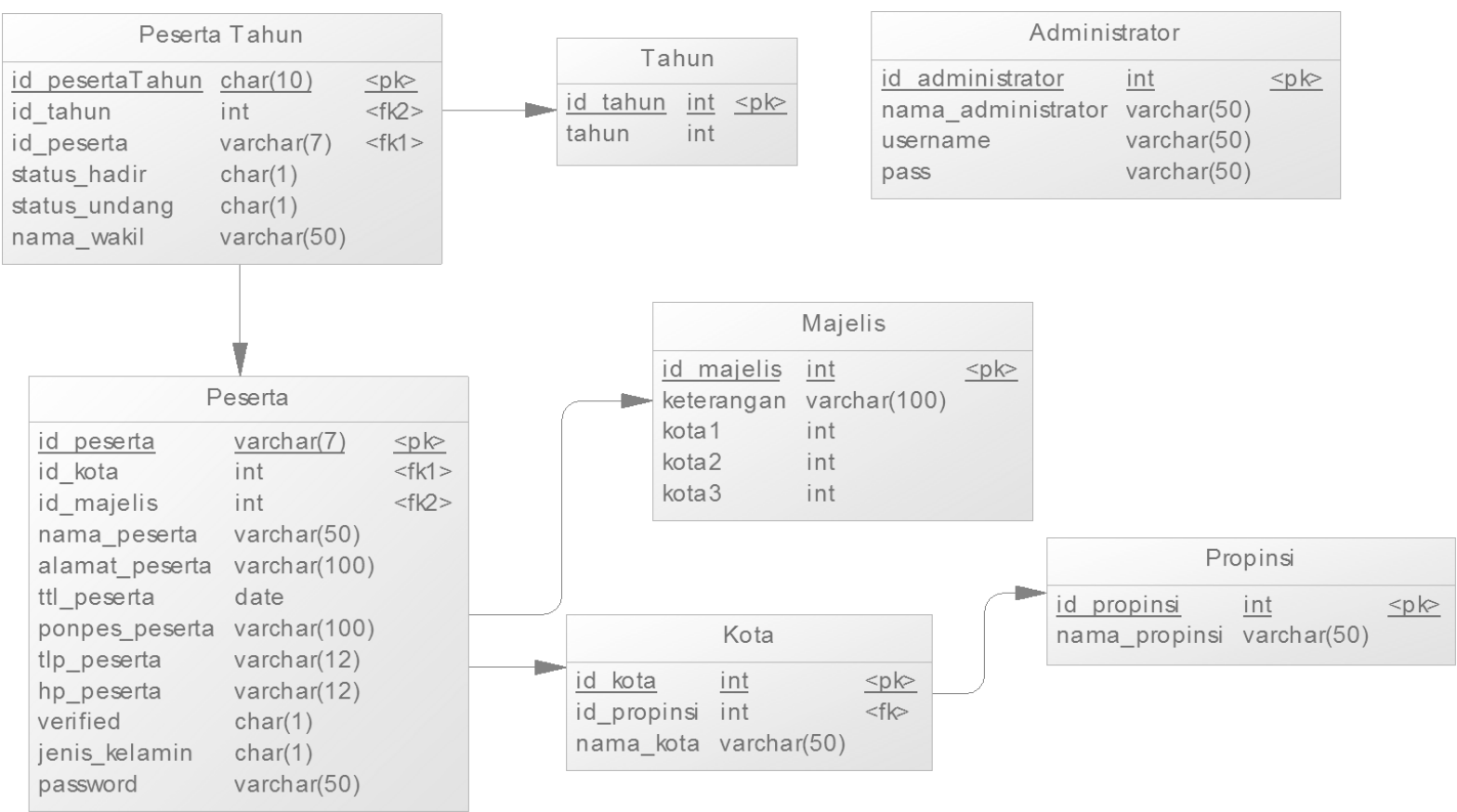

Gambar 3 Physical Data Model dari database Sistem Informasi Absensi Haul

\subsection{Perancangan Database}

Database pada sistem infromasi absensi ini terdiri atas tujuh tabel. Tabel tersebut adalah tabel peserta, tabel majelis, tabel kota, tabel propinsi, tabel tahun, tabel peserta tahun, dan tabel administrator. Tabel peserta digunakan untuk menyimpan informasi peserta. Begitu juga dengan tabel majelis, kota, propinsi, tahun, dan administrator. Tabel-tabel tersebut berfungsi untuk menyimpan data majelis, kota, propinsi, tahun, dan administrator. Sedangkan tabel peserta tahun adalah tabel yang berfungsi untuk menyimpan informasi tentang status kehadiran peserta di tahun tertentu seperti yang ditunjukkan oleh Physical Data Model pada Gambar 3. 
Tabel 1 Informasi dikemposisi modul

\begin{tabular}{cll}
\hline No & \multicolumn{1}{c}{ Modul } & \multicolumn{1}{c}{ Keterangan } \\
\hline 1 & Modul Registrasi & $\begin{array}{l}\text { Modul ini digunakan untuk pendaftaran peserta Haul secara } \text { online dengan } \\
\text { cara mengisikan identitas dari calon peserta }\end{array}$ \\
2 & Modul Login Peserta & $\begin{array}{l}\text { Modul ini digunakan untuk login sebagai peserta Haul } \\
\text { Modul ini digunakan untuk memverifikasi dan memvalidasi calon peserta }\end{array}$ \\
3 & Modul Verifikasi dan Undang & $\begin{array}{l}\text { Haul } \\
\text { Modul ini dipergunakan untuk absen peserta secara online, serta penentuan } \\
\text { majelis peserta secara realtime }\end{array}$ \\
4 & Modul Absensi & Modul ini digunakan untuk mencari peserta berdasarkan nomor identitas, \\
5 & Modul Laporan Peserta & maupun berdasarkan tahun, jenis kelamin, dan setatus kehadiran \\
6 & Modul Majelis & Modul untuk menampilkan majelis peserta berdasarkan nomor identitas \\
7 & Modul Pengaturan Majelis & $\begin{array}{l}\text { Modul ini digunakan untuk me-reset } \text { majelis peseta dan menghapus data } \\
\text { majelis. }\end{array}$ \\
\hline
\end{tabular}

\section{Hasil Penelitian dan Pembahasan}

Pada bagian implementasi dan pengujian ini, penulis akan membahas tentang proses dan hasil implementasi sistem. Hasil pengujian sistem dengan metode Black Box juga akan dibahas dalam bagian ini.

\subsection{Implementasi Sistem}

Sistem diimplementasikan menggunakan bahasa pemrograman PHP dan Javascript. Sedangkan DBMS (Database Management System) yang digunakan adalah MySQL. Hasil implementasi modul registrasi ditampilkan pada Gambar 4, Gambar 5, dan Gambar 6. Gambar 4, merupakan tampilan dari form registrasi peserta. Jika peserta telah selesai mengisi form ini, peserta harus menekan tombol "Daftar". Setelah itu, akan ada notifikai seperti Gambar 5. Hasil dari proses registrasi berupa nomor identitas dan password. Nomor identitas dan password ini digunakan untuk log in ke sistem informasi absensi Haul. Agar peserta dapat menyimpan nomor identitas dan password-nya, sistem menyediakan fasilitas mencetak nomor identitas dan password tersebut seperti yang ditampilkan oleh Gambar 6.

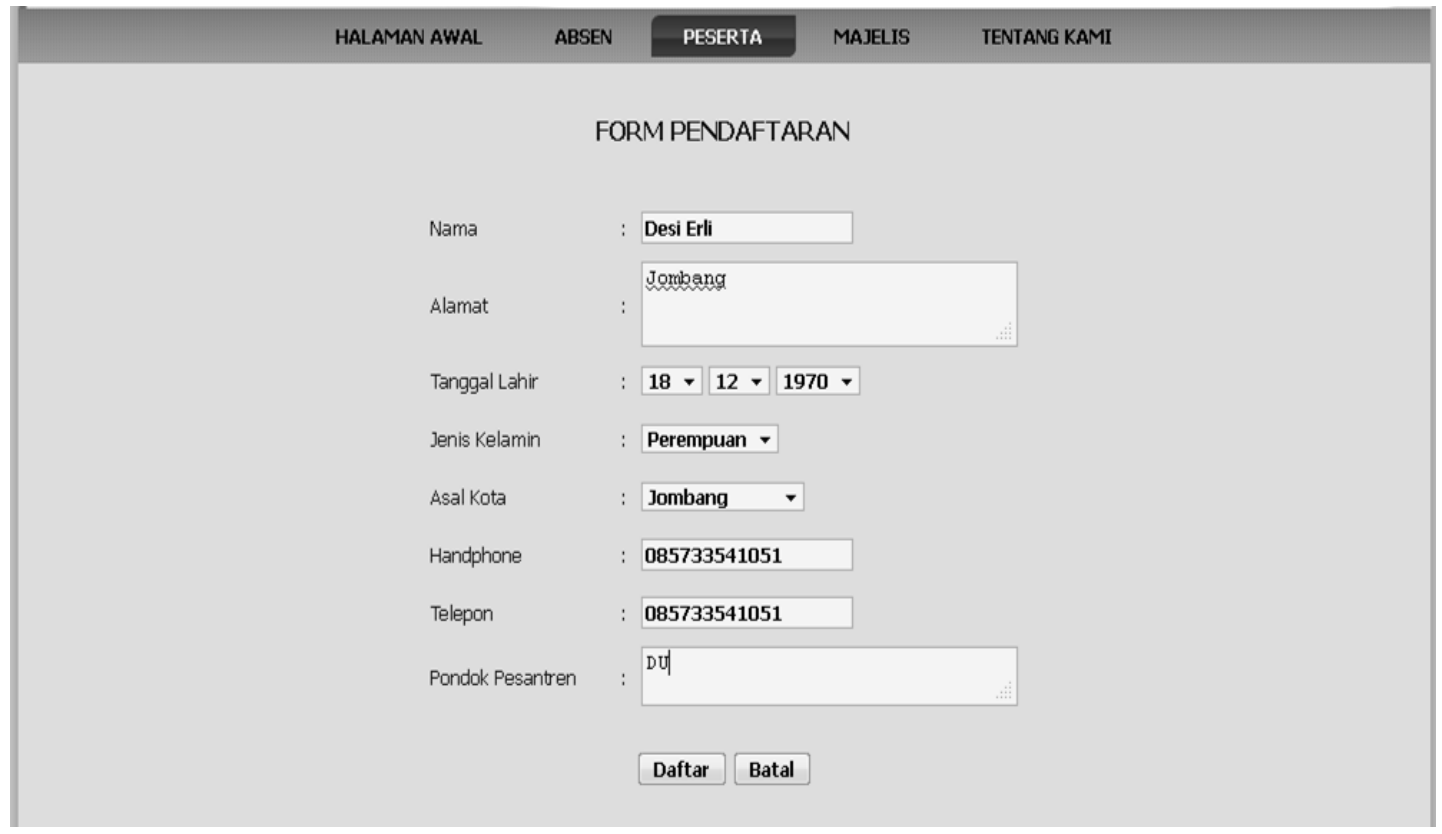

Gambar 4 Form registrasi peserta Haul

Setelah peserta berhasil registrasi, peserta mempunya nomor identitas dan password yang dapat digunakan untuk log in ke sistem informasi absensi Haul. Tampilan halaman log in dapat dilihat pada Error! Reference source not found.7. Peserta dapat melakukan edit data/profil seperti pada tampilan Error! Reference source not found.8. 
Modul verifikasi dan undang ini hanya dapat diakses oleh admin. Peserta yang berhasil registrasi tidak dapat langsung diundang untuk datang ke acara Haul. Admin perlu melakukan verifikasi terlebih dahulu. Halaman verifikasi peserta ditampilkan pada Gambar 9. Jika sudah terverifikasi, peserta dapat diundang ke acara Haul PP. Muhyiddin. Tampilan halaman undang peserta disajikan pada Gambar 10. Fasilitas undang peserta pada sistem ini berfungsi untuk mengubah status undang peserta di database menjadi "diundang". Jika status peserta "tidak diundang", maka peserta tersebut tidak dapat diabsen ketika acara Haul berlangsung meskipun peserta tersebut datang. Hal ini mempermudah panitia dalam memeriksa apakah peserta yang datang pada acara Haul tersebut benar-benar diundang atau kah tidak. Sebab selama ini terdapat beberapa peserta yang datang padahal tidak diundang.

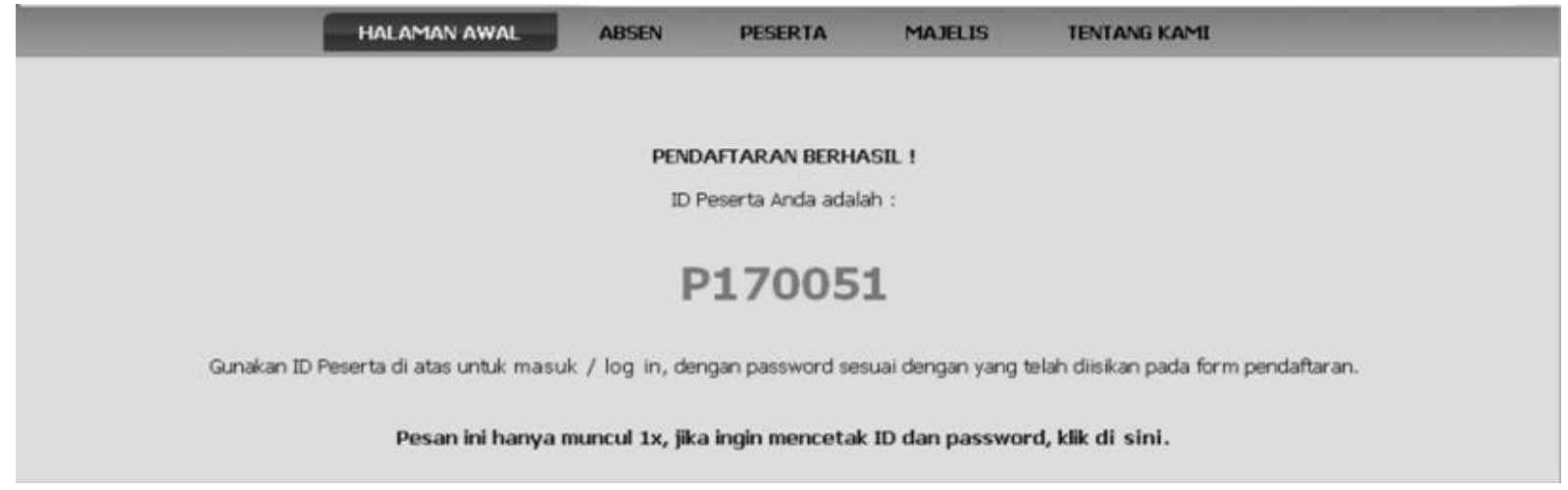

Gambar 5 Notifikasi bahwa proses registrasi berhasil

\section{ID PESERTA P170051 \\ PASSWORD P170051}

Simpan baik-baik ID PESERTA dan PASSWORD ini, karena akan digunakan seterusnya untuk masuk / log in ke website Haul PP. Muhyiddin.

Gambar 6 Tampilan hasil registrasi versi cetak, berisi nomor identitas peserta dan password

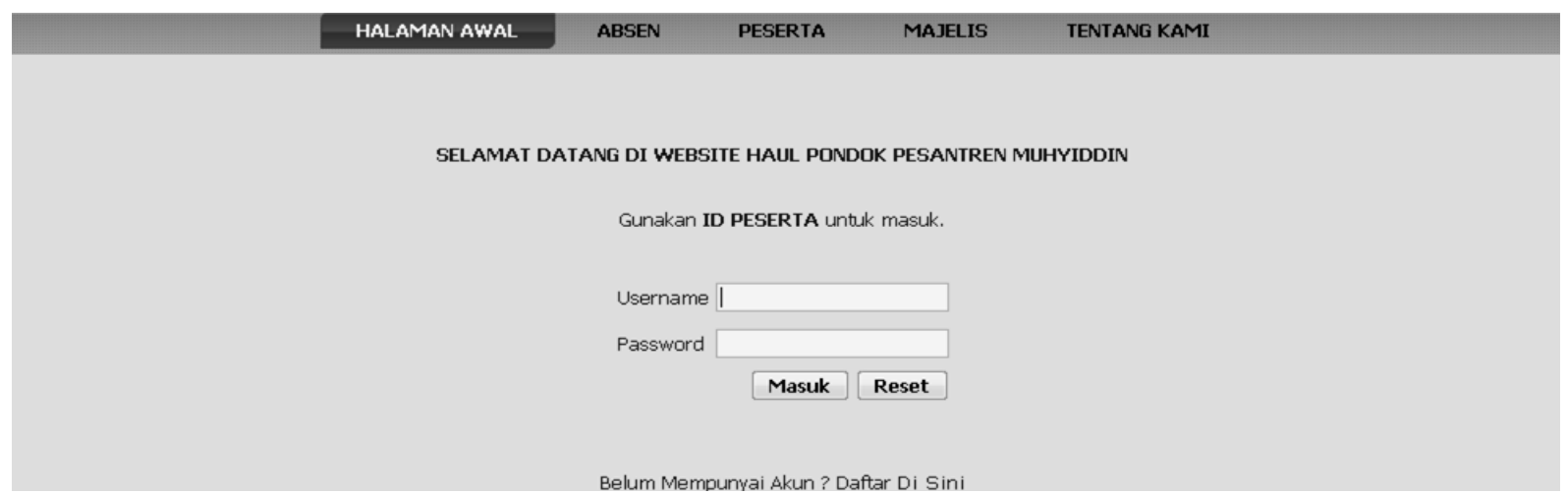

Gambar 7 Halaman $\log$ in peserta

Saat acara Haul berlangsung, ratusan peserta akan datang tiap hari. Panitia harus melakukan proses absensi dan pembagian majelis berdasarkan urutan kedatangan dan kota asal. Proses absensi dilakukan dengan cara mengetikkan nomor identitas peserta pada kolom pencarian peserta seperti pada Gambar 11. Jika peserta tersebut berstatus "diundang", maka datanya akan muncul sebagai hasil dari proses pencarian peserta. Panitia dapat memilih tombol "Hadir" atau "Diwakilkan" seperti yang ditunjukkan oleh Gambar 12. Jika statusnya "Diwakilkan", maka kolom nama wakil harus diisi. Jika tidak diisi, maka sistem akan menampilkan peringatan kesalahan. Dan proses absensi tidak berhasil. Ketika admin menekan tombol "Hadir" atau "Diwakilkan", maka secara otomatis akan muncul satu tab lain di browser. Tab tersebut berisi kartu peserta Haul yang siap cetak seperti yang ditampilkan oleh Gambar 13. Kartu peserta haul tersebut berisi informasi identitas peserta, status kehadiran peserta, dan 
nomor majelis peserta. Nomor majelis peserta ini merupakan hasil proses pembagian majelis yang real time dan otomatis dilakukan oleh sistem ketika user menekan tombol "Hadir" atau "Diwakilkan".

\section{EDIT PROFIL PESERTA}

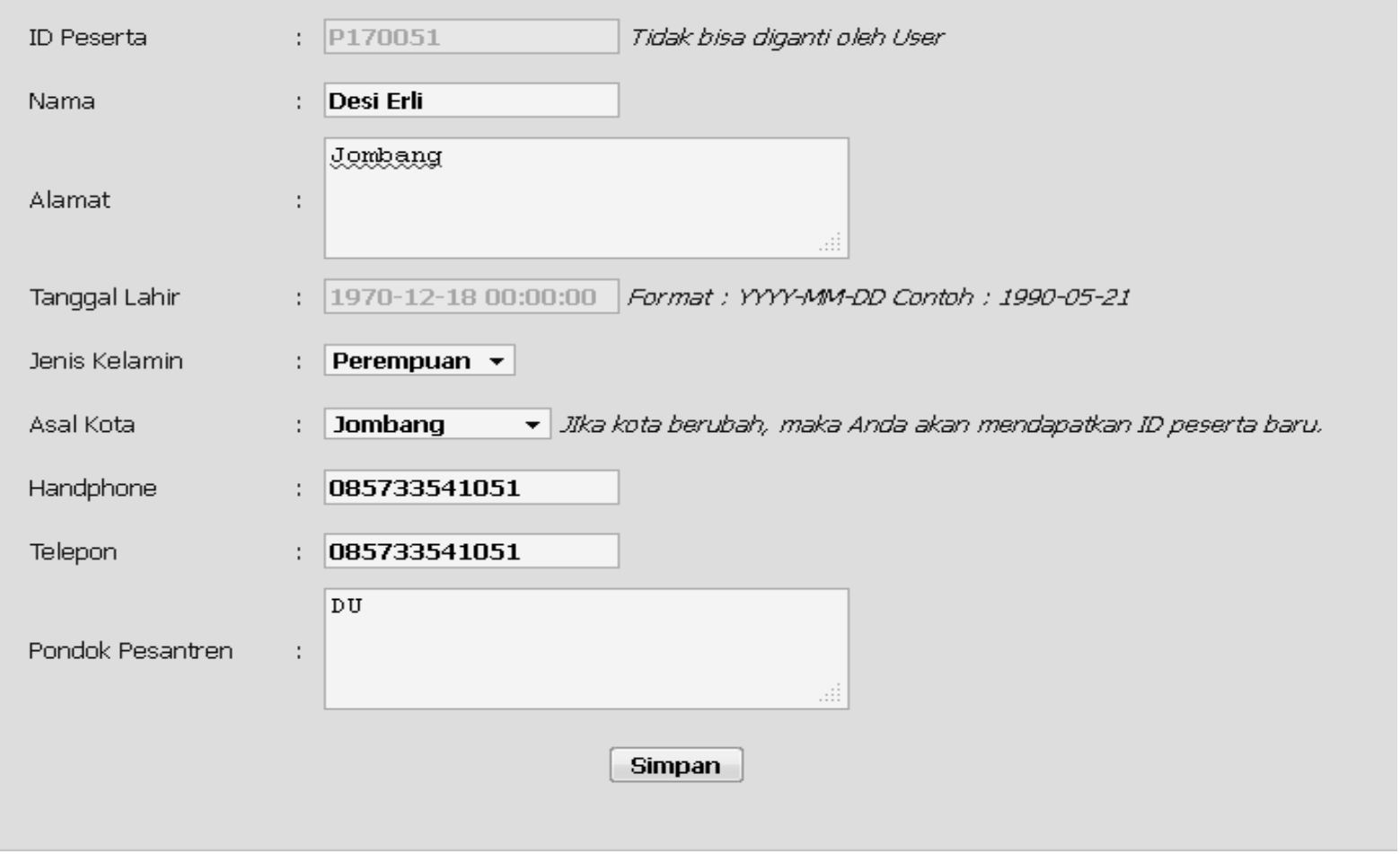

Gambar 8 Halaman edit profil peserta

\begin{tabular}{|c|c|c|c|c|c|c|}
\hline & \multicolumn{2}{|c|}{ Jenis Kelamin } & \multicolumn{2}{|c|}{ Status Verifikasi } & Perintah & \\
\hline & Semua & - & Semua & Cari & Batal Verifikasi & \\
\hline Nomor & Nama & & & Kota & Verifikasi & Verifikasi/Tidak \\
\hline L010001 & Ust. H.Tamhid Thurmudzi & & & Bangkalan & Sdh. Diverivikasi & Q \\
\hline L010002 & Ust. Kholil & & & Bangkalan & Sdh. Diverivikasi & Q \\
\hline L010003 & Ust. Ridwan & & & Bangkalan & Sdh. Diverivikasi & $\square$ \\
\hline L010004 & Ust. Muzakki & & & Bangkalan & Sdh. Diverivikasi & $\square$ \\
\hline L010005 & Ust. Samsul Hadi & & & Bangkalan & Sdh. Diverivikasi & 回 \\
\hline L010006 & Ust. Abd. Mu'thi & & & Bangkalan & Sdh. Diverivikasi & $\square$ \\
\hline L010007 & Ust. Suryadi & & & Bangkalan & Sdh. Diverivikasi & 回 \\
\hline L010008 & Ust. H. Mufakkir & & & Bangkalan & Sdh. Diverivikasi & $\square$ \\
\hline L010009 & KH. Idham Kholid & & & Bangkalan & Sdh. Diverivikasi & $\square$ \\
\hline L010010 & Ust. H. Dlofir & & & Bangkalan & Sdh. Diverivikasi & 回 \\
\hline L010011 & Ust. H. Marzuki & & & Bangkalan & Sdh. Diverivikasi & 回 \\
\hline L010012 & Ust. Fauzi & & & Bangkalan & Sdh. Diverivikasi & $\square$ \\
\hline L010013 & Ust. Kholil & & & Bangkalan & Sdh. Diverivikasi & 回 \\
\hline L010014 & Ust. Bahrun & & & Bangkalan & Sdh. Diverivikasi & $\square$ \\
\hline L010015 & Ust. Abd. Halim & & & Bangkalan & Sdh. Diverivikasi & 回 \\
\hline L010016 & Ust. Mas'ud Fauzan & & & Bangkalan & Sdh. Diverivikasi & $\square$ \\
\hline L010017 & Ust. Fauzan & & & Bangkalan & Sdh. Diverivikasi & 回 \\
\hline L010018 & Ust. Abd. Ghoni & & & Bangkalan & Sdh. Diverivikasi & $\square$ \\
\hline L010019 & Ust. Moh Muslih & & & Bangkalan & Sdh. Diverivikasi & 回 \\
\hline L010020 & Ust. Ridlo'i & & & Bangkalan & Sdh. Diverivikasi & $\square$ \\
\hline L010021 & Ust. Amrini Angsar & & & Bangkalan & Sth. Diverivikasi & 回 \\
\hline L010022 & Ust. Bahrul Mustajab & & & Bangkalan & Sdh. Diverivikasi & $\square$ \\
\hline L010023 & Ust. Ridhoi & & & Bangkalan & Sdh. Diverivikasi & 回 \\
\hline
\end{tabular}

Gambar 9 Tampilan halaman verifikasi peserta yang telah berhasil registrasi

Pada saat acara Haul sedang berlangsung atau pun sudah selesai, setiap user baik admin mau pun non-admin dapat melihat laporan peserta. Laporan peserta akan ditampilkan berdasarkan kriteria pencarian. Kriteria tersebut meliputi tahun Haul, status undangan peserta,status kehadiran peserta, jenis kelamin, kota, dan nomor majelis. Selain menampilkan laporan peserta, sistem juga menyediakan fasilitas cetak laporan peserta seperti yang ditampilkan oleh Gambar 14. 
Peserta yang kartu pesertanya hilang dapat mencetak ulang kartu pesertanya melalui halaman fasilitas lihat nomor majelis. Tampilan dari fasilitas lihat nomor majelis peserta disajikan pada Gambar 15. Modul pengaturan dapat diakses oleh user admin. Pengaturan majelis merupakan dua menu teratas yang ada pada halaman beranda admin seperti yang ditampilkan oleh Gambar 16. Dua menu tersebut adalah "Reset Majelis" dan "Reset Majelis Peserta". "Reset Majelis" digunakan untuk menghapus semua data majelis pada database. Sedangkan "Reset Majelis Peserta" digunakan untuk mengubah nomor majelis semua peserta menjadi NULL.

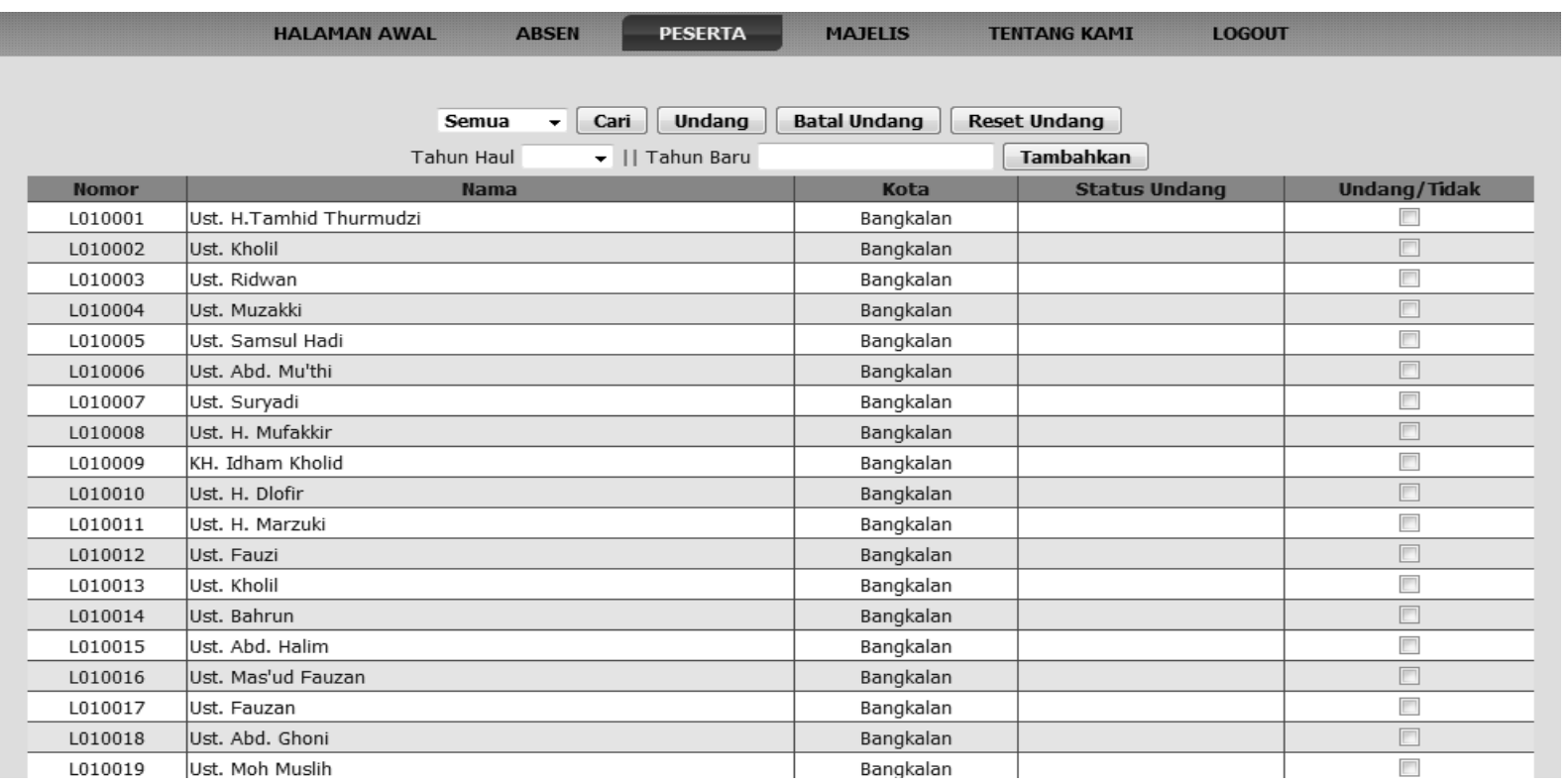

Gambar 10 Tampilan halaman ubah status undang peserta

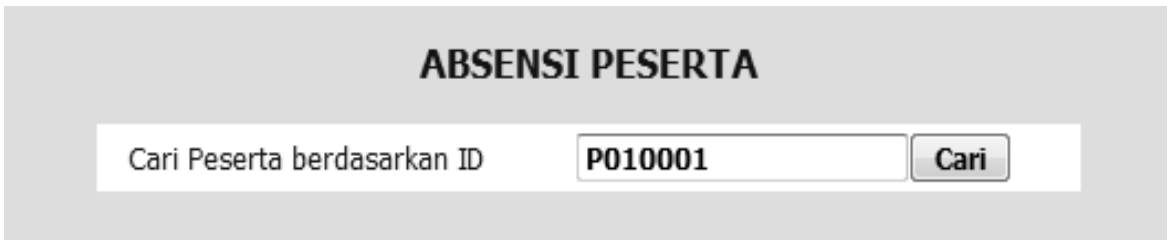

Gambar 11 Tampilan form cari peserta untuk dilakukan proses absensi

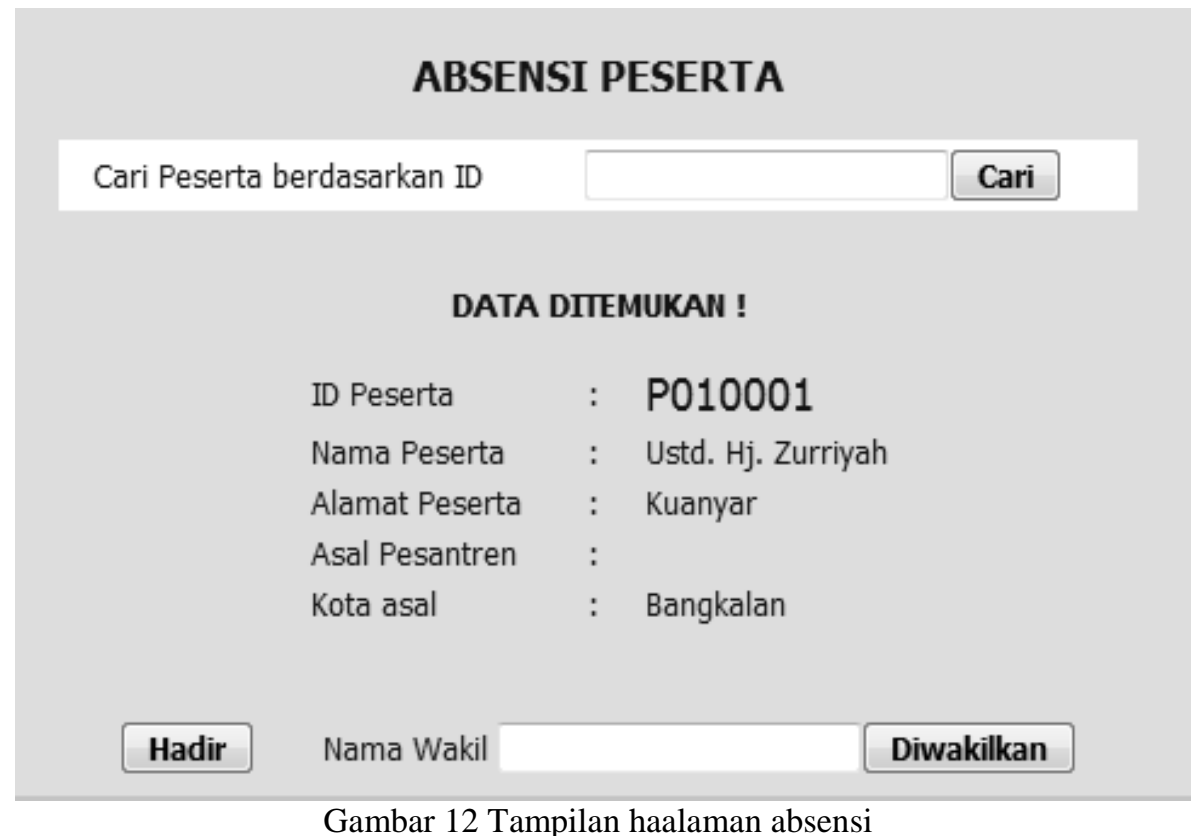




\subsection{Pengujian Sistem}

Penulis menggunakan metode Black Box Testing untuk menguji sistem yang telah dibuat. Pengujian ini bertujuan untuk memerika fungsionalitas dari sistem yang telah dibuat, apakah berjalan sesuai rancangan atau tidak.

Uji coba modul absensi dilakukan dengan cara melakukan simulasi mengabsen 100 peserta dari tiga buah laptop. Ketiga laptop tersebut dikoneksikan ke dalam suatu jaringan localhost.

Hasil uji coba menunjukkan tidak ada masalah pada sistem absensi ketika kecepatan memasukkan data adalah 2 data/menit, 3 data/menit, dan 5 data/menit. Namun, terjadi kesalahan dalam penentuan majelis ketika kecepatan menginputkan data adalah 10 data/menit seperti yang disajikan dalam Tabel 2 .

\begin{tabular}{|c|l|l|}
\hline ID & L010001 & \\
\hline NAMA & Ust. H.Tamhid Thurmudzi & \\
\hline \hline ALAMAT & PP. Tahfidhul Qur'an AI Ashror JI. Sukarno Hatta No 32 C \\
\hline KOTA & Bangkalan & \\
\hline PROPINSI & Jawa Timur & \\
\hline TELEPON & 0133092602 \\
\hline HP & 085232155497 & \\
\hline STATUS & Hadir $/$ - \\
\hline
\end{tabular}

Untuk semua peserta harus mempunyai nomor ID dan Nomor Majelis, apabila ID atau print out Nomor Majelis berpindah tangan maka panitia tidak bertanggung jawab.

Gambar 13 Contoh tampilan kartu peserta Haul

\section{Haul PP. Muhyiddin 2011}

\begin{tabular}{|c|c|c|c|c|c|c|}
\hline Majelis & Nomor & Nama & Alamat & Kota & Telepou & HPP \\
\hline L010001 & Ust H Tembid Turanudsi & 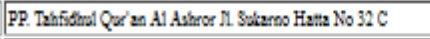 & Bengtalun & & & \\
\hline Lo10002 & Ust Khoull & PP. Deral Qu'z Konang & Bengialun & & & \\
\hline L010004 & Ust Nonzldi & PP. Daral Qu's Ronang & Bughtalun & & & \\
\hline Lo10005 & Ust Sanasul Hadi & PP. Deral Qu'z Konang & Bengivina & & & \\
\hline L010006 & Ust Abd Mestai & PP. Daral Qu' a Konang & Bengtalin & & & \\
\hline Lo10008 & Ust H. Nofition & Dess Benjuz Gala & Bengivalun & & & \\
\hline L010009 & KH Idhan Kholid & PP. Deral Qu' a Konzan & Bengheina & & & \\
\hline L010010 & Ust H. Dlofir & II Raye Gala & Bengtalin & & & \\
\hline Lo10011 & Ust H. Mrasis & Ds Krangzen Timur Galin & Bengitaina & & & \\
\hline L010012 & Un Fusi & 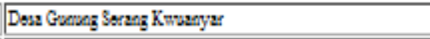 & Benghalun & & & \\
\hline L010016 & Ust Masd Fusum & PP. Nend Kholl & Bengtaina & & & \\
\hline L010017? & Unt Fosm & Sopurah Galis & Bengtailun & & & \\
\hline L010018 & Ust Abd Ghosi & Den Glogz D RrengzenTinza Grlis & Bengalen & & & \\
\hline L010019 & Ust Moh Nosily & 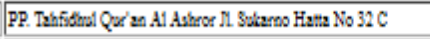 & Bengtalun & & & \\
\hline L010020 & Ust Ristloi & Tangh Norah & Bengalun & & & \\
\hline L010021 & Ust Anarixi Angas & Kuruyz: Bur: & Bengialun & & & \\
\hline Talom & The Ratholl Mowaigh & 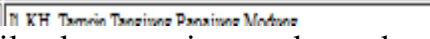 & Rimatiolim & & & \\
\hline
\end{tabular}

Gambar 14 Contoh tampilan laporan siap cetak untuk peserta Haul yang berasal dari Bangkalan

\section{LIHAT NOMOR MAJELIS PESERTA}

Lihat Majelis berdasarkan ID Peserta

P010001

Cari

Gambar 15 Fasilitas lihat nomor majelis peserta yang diperuntukkan bagi peserta yang lupa nomor majelisnya atau hilang kartu peserta Haul-nya. 
Kesalahan pertama yaitu majelis terdiri dari empat peserta atau lebih, padahal maksimum tiga peserta dalam satu majelis. Hal ini terjadi karena logika yang diterapkan pada modul absensi khusunya bagian pembagian majelis masih belum efektif dalam hubungannya dengan sistem jaringan. Dua user mengabsen peserta yang berbeda dalam waktu yang bersamaan. Sehingga kedua peserta tersebut masuk ke dalam majelis yang sama, padahal kuota majelis hanya tersisa satu.

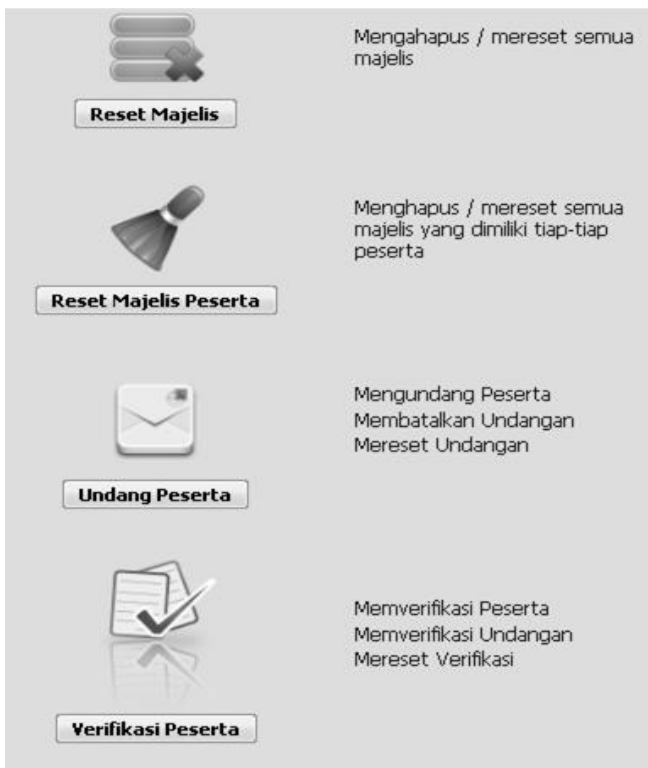

Gambar 16 Tampilan halaman beranda admin

Tabel 2 Hasil uji coba modul absensi.

\begin{tabular}{ccccc}
\hline $\begin{array}{c}\text { Kecepatan } \\
\text { memasukkan } \\
\text { data }\end{array}$ & $\begin{array}{c}\text { Prosentase } \\
\text { Benar }\end{array}$ & & \multicolumn{3}{c}{\begin{tabular}{c} 
Prosentase Kesalahan \\
\cline { 3 - 5 }
\end{tabular}} & $\begin{array}{c}\text { Majelis terisi }> \\
3 \text { peserta }\end{array}$ & $\begin{array}{c}\text { Majelis mengandung peserta dari kota } \\
\text { yang sama }\end{array}$ & $\begin{array}{c}\text { Peserta yang } \\
\text { absen } 2 \mathrm{x}\end{array}$ \\
\hline 2 data/menit & $100 \%$ & $0 \%$ & $0 \%$ & $0 \%$ \\
3 data/menit & $100 \%$ & $0 \%$ & $0 \%$ & $0 \%$ \\
5 data/menit & $100 \%$ & $0 \%$ & $0 \%$ & $0 \%$ \\
10 data/menit & $97 \%$ & $2 \%$ & $1 \%$ & $0 \%$ \\
\hline
\end{tabular}

Kesalahan kedua juga disebabkan oleh hal yang sama seperti kesalahan pertama. Dua user mengabsen dalam waktu yang bersamaan dan secara tidak sengaja kedua peserta yang diabsen oleh user tersebut berasal dari kota yang sama. Dan keduanya dimasukkan ke dalam majelis yang sama, padahal kuota majelis hanya tersisa satu dan seharusnya dalam satu majelis tidak boleh ada peserta yang berasal dari kota yang sama.

Selain dari kesalahan tersebut, tidak ada kesalahan lain yang terjadi. Baik di modul absensi maupun di modul-modul yang lain. Semua fungsionalitas sistem berjalan sesuai dengan yang telah diencanakan.

\section{Kesimpulan}

Aplikasi Sistem Informasi Absensi Haul ini memiliki desain antar muka yang sederhana sehingga memudahkan user dalam menjalankan aplikasi. Sistem yang dibangun berbasis web memungkinkan beberapa user menggunakannya dalam waktu yang bersamaan. Database pun dapat diakses bersamaan secara online. Hal ini membuat proses absensi Haul menjadi lebih efisien. Jika tidak manggunakan sistem, tentunya waktu satu menit tidak cukup untuk mengabsen peserta Haul. Karena panitia juga harus melakukan pembagian majelis secara manual dan mencetak kartu peserta Haul. Namun masalah tersebut kini telah teratasi dengan adanya Sistem Informasi Absensi Haul. Dalam satu menit, panitia dapat 
mengabsen beberapa peserta, membagi majelis peserta berdasarkan urutan kedatangan, serta mencetak kartu peserta Haul.

\section{Referensi}

Bodnar, G. H., \& Hopwood, W. S. (2004). Sistem Informasi Akuntansi. (A. A. Jusuf, \& R. M. Tambunan, Penerj.) Jakarta: Salemba Empat.

Nuh, M. (2012). Pembangunan Sistem Informasi Presensi Siswa Pada Sekolah Menegah Atas (SMA) Negeri 1 Rembang Berbasis Finger Print. Journal Speed - Sentra Penelitian Engineering dan Edukasi , 4(4), 1-5.

Santoso, L. W., Setiawan, A., \& Purwanto, W. (2010). Pembuatan Sistem Informasi Presensi Pada Universitas Kristen Petra. Seminar Nasional Teknologi Informasi, (pp. 1-8).

Subair, M. (2010). Perancangan Sistem Informasi Presensi Berbasis Sidik Jari Kehadiran Mahasiswa STMIK AMIKOM. Yogyakarta: STMIK AMIKOM.

Suprihatin, \& Nurhantara, A. (2011). Sistem Informasi Presensi Menggunakan Sidik Jari (Study Kasus Presensi Perkuliahan Program Studi Sistem Informasi FMIPA UAD). JUSI, 1(2), 137-150. 